\title{
Performing 'L-'alwa': a sacred and erotic journey in Morocco
}

\section{Alessandra Ciucci}

To cite this article: Alessandra Ciucci (2017) Performing 'L-'alwa': a sacred and erotic journey in Morocco, Ethnomusicology Forum, 26:2, 151-170, DOI: 10.1080/17411912.2017.1338595

To link to this article: http://dx.doi.org/10.1080/17411912.2017.1338595

$$
\text { 曲 Published online: } 06 \text { Jul } 2017 .
$$

Submit your article to this journal $₫$

III Article views: 35

Q View related articles $₫$

View Crossmark data $\nearrow$ 


\title{
Performing 'L-calwa': a sacred and erotic journey in Morocco
}

\author{
Alessandra Ciucci (D) \\ Department of Music, Columbia University, New York, NY, USA
}

\begin{abstract}
'L-'alwa', a sung poem whose text recounts the pilgrimage to a saint's shrine in Morocco, is celebrated for its ability to convey images and emotions stirred up by the sacred journey. As part of the repertory of 'aita-a genre of sung poetry from the Moroccan plains and plateaus traditionally performed by professional female singer-dancers [shikhat] and nowadays categorised as popular music [sh'abi]-'L-'alwa' presents an interesting case study through which it is possible to analyse the porosity between local constructions of the sacred and the secular in relation to a genre which is not explicitly associated with the sacred or with sacred performances. My analysis of salient moments of a performance of 'L-'alwa' at a wedding celebration in Morocco explores how the shikhat move across the sacred and the secular, and the central role that eroticism [ghram or mshka] plays in the porosity between these categories in performance.
\end{abstract}

\section{KEYWORDS}

Morocco; sung poetry; female performers; sakən; 'aița; eroticism

\section{Introduction}

wa l-ghadi l-'alwa t'ala nwașsik bo'da

You, who are going to the 'alwa come [here] first so that I can advise you ${ }^{1}$

In Morocco the term sakan (lit. spirit, sentiment, passion; from the verb skan, to become calm, to live, dwell, inhabit, to be possessed by a spirit) refers to a sung poem dedicated to a wali, a friend of God, a saint. ${ }^{2}$ Sakan has been defined in a number of ways by scholars: as a genre per se (Bouhmid 1992, 1995: 6; Kapchan 1996: 210n5, 2003: 264n8), as a type of popular song characterised by a spiritual aspect (Raggoug 2008: 23-6), as sung poetry connected to a dance associated with trance (Yaktin 2008: 6), as 'the melody the body occupant desires to hear and dance on' (Maarouf 2010: 637) and as religious song or spiritual

\footnotetext{
CONTACT Alessandra Ciucci amc25@columbia.edu

${ }^{1}$ In my rendering of the colloquial Arabic used in everyday life in Morocco I have adopted the IJMES (International Journal of Middle East Studies) system for consonants. For vowels, I have diverged from this system, because in Moroccan Arabic the differences in vowel length are not as distinctive as in standard Arabic. In order to represent Moroccan pronunciation, I have employed full vowels ( $a, u$ and $i)$ and short vowels ( $\partial, 0$ and e). Because so many French and English forms and transliterations have become standard, place names, tribes and proper names are written as they have been conventionally transliterated in Morocco. I have kept the letter ayn ( $\left.{ }^{c}\right)$ in all of these transliterations. Spellings used by other authors are retained when I reference or quote their publications.

${ }^{2}$ Notwithstanding the differences in meaning between wali, murabit [someone connected to a ribat or a Sufi lodge], șalih [virtuous or pious], sidi [master, lord, mister] and mulay [title given to a descendent of the Prophet Mohammed] (Cornell 1998; Reysoo 1991; Rhani 2013), all of these terms are used as synonyms for saint in Morocco. The use of the term saint, however, must be understood in reference to Islam - as the friend of God who is also the protector and patron of lesser Muslims, not to be confused with the Christian concept of sainthood (Cornell 1998: xvii-xxxiii; Zeghal 2009: 589). 
music within the genre of 'aita (Najmi 2007 Vol. 2: 132). Whereas all of these definitions acknowledge the association of sakan with the sacred, they differ in the way in which the term is used in particular repertoires. Thus, if for ritual musicians connected to a religious order [tariqa, lit. path] like the Hamadsha or the 'Aissawa, sakan is one of the general terms used to refer to their tunes, for the musicians I have worked with sakan refers to the sacred component of 'aita, a genre of sung poetry from the Moroccan plains and plateaus which is nowadays categorised at the juncture between the 'folk' and the 'popular' under the umbrella term shabi. ${ }^{3}$

Drawing from my work with musicians of 'aita, I discuss sakan in the ways in which my interlocutors understand it, using a performance of a particular sakən 'L-'alwa' as a case study to analyse the porosity between the categories of the sacred and the secular in a traditional context of performance: a wedding celebration ['ars] in Morocco. ${ }^{4}$ A sung poem whose text recounts the pilgrimage to a saint's shrine in Morocco, 'L-'alwa' is celebrated for its ability to convey images and emotions stirred up by the sacred journey. Yet as part of the repertory of 'aita-a genre which is not explicitly associated with the sacred or with sacred performances-'L-'alwa' can be heard via commercial recordings, the Internet, television and radio, and experienced live sung by different artists in various contexts of performance. Here, I am particularly interested in how the shikhat-professional female singer-dancers who, accompanied by male instrumentalists, have historically been considered the principal interpreters of 'aita-move across these two categories in the course of performance.

In anthropology, the influential work of Talal Asad (2003) has marked a critical debate and rethinking of the categories of the sacred and the secular, regarding them as interwoven with one another, particularly in reference to Islam. If a number of researchers had already remarked, albeit not theorised, the permeability between the sacred and the secular in their works on the music of the Middle East and North Africa, Asad's work has had an important impact on more recent studies on the music of this region, and, more germane to this article, on that of Morocco. The permeability between the sacred and the secular has been discussed, directly or indirectly, in reference to the texts of alala or the so-called Andalusian music (Davila 2013), those of the malhun (Jirari 1970; Jouad 2002; Magidow 2016; Schuyler 1974), in relation to the poetry of the Berbers of the Atlas Mountains (Lortat-Jacob 1980; Rovsing-Olsen 1997) and to the performances of Berber professional musicians from south-western Morocco (Schuyler 1979). Other studies have focused on analysing the co-existence of sacred and secular sounds, music styles and gestures in traditional, staged and mediated performances associated with

\footnotetext{
${ }^{3}$ The term sh'abi [from sh $a b$, lit. folk, people] in Morocco has been discussed by a number of scholars: Jeff Callen, translates it as 'popular' in the sense 'of the people' (2006: 31-2); Tarik Sabry posits that it refers to its working-class audience and, implicitly, their listening modes (2010: 54-7); Brian Karl defines it as a meta-genre, as a 'highly absorbent and somewhat fluid category of cultural practice that subsumed or intertwined with a great number of other distinct genres or subgenres' (2012: 17); and Lhoussain Simour argues for its critical role in understanding the heterogeneous character of Moroccan identity (2016: 7-20).

${ }^{4}$ Recognising the popularity of 'L-'alwa' in Morocco, a number of authors have cited this sakən prior to my discussion. Deborah Kapchan quotes a number of verses from 'L-'alwa', but she does not identify it is a sakan nor its sacred association or location when she writes that l'alwa, the heights, is a metaphor for the city (1996: 202). Jésus Aguila and Mokhtar Zagzoule, on the other hand, identify the association with the sacred in their discussion of 'L-'alwa', but they mistakenly associate it with the pilgrimage to Sidi 'Omar ben Lahsen (2000: 178-9). Allal Raggoug describes 'L-'alwa' as a simplified 'aita which renders homage to different saints of the Casablanca-Settat region in Morocco. Raggoug recognises its association with the sacred, and also states that 'L-'alwa' has become popular thanks to a number of performers, and that is constantly requested by the audiences and associated with trance (2008: 52-3).
} 
Sufism, religious orders and Islamist artists (see Baldassarre 1999; Curtis 2015; Fuson 2009; Kapchan 2007; Laan 2012, 2016; Langlois 1999; Majdouli 2014; Nabti 2010; Schaefer 2015; Schuyler 1981; Sum 2011; Witulsky 2016). Similar discussions have also emerged in reference to hip hop, its performances and the formation of an ethical Muslim counterpublic (Aidi 2014; Salois 2014). Writings centred on the analysis of performance have engaged, directly or indirectly, with the role and the effects of audition [samac] in the region and in Islam, focusing on the boundaries between ritual and entertainment and, more specifically, on the analysis of movements, gestures, music styles, 'stage talk' and verbal and non-verbal audience responses.

In this article, however, I aim to engage with two specific local constructions of the categories of sacred and secular in performances of 'aita, in which sakan indexes the sacred, while nashat [lit. pleasure, enjoyment, enthusiasm; from the verb nshot, to rejoice, to have fun, to be happy] indexes the secular. I argue that performers of 'aita knowingly move across these two categories in order to produce the desired festive atmosphere [jaw], and those climactic moments in performance that they refer to as l-khadma tal'at [the work has gone up]:

The guests are always looking at what we do next. We know that they wait for us. And it is then that we need to give them something at a high level ... usually, it is in the middle or at the end of the evening that we perform a sakan. (Ouled ben Aguida, personal communication, Safi, 6 March 2004)

In this context I analyse the central role that ghram [lit. passion, ardent desire, eroticism] or mshka [lit. complaint, moan, groan] play in the porosity between the categories of sacred and secular in performance, between sakan and nashat and, more in particular, the role of ghram or mshka in the poetic text and its interpretation. Whereas ghram indicates eroticism in both standard Arabic and Moroccan colloquial Arabic, mshka is only used among the performers of 'aița. As part of their argot [ghus], mshka in fact refers to love and eroticism.

The role of the shikhat in performance has been analysed by a number of scholars whose writings have largely focused on the dialectic between propriety and impropriety in reference to Moroccan cultural mores with particular emphasis on the body (see Ciucci 2012b). Deborah Kapchan (2003) has explored the role of gender in the creation of nashat, which she aptly describes as a particular emotional state of celebration associated with the secular. Kapchan discusses what she refers to as the 'thin but distinct line' between nashat and jedba [trance], delineating the relationship between the two states and how they 'both co-occur in musical contexts' (2003: 262). Borrowing from linguists, Kapchan's co-occurrence focuses on an 'economy of trance gesture' repeated and circulated in other contexts of performance, and on the moment in which 'nashat breaks into trance', when 'the ludic aspect of performance transforms into the seriousness of ritual' (2003: 262). Although Kapchan uses pertinent local constructions of the sacred and the secular, she discusses the sacred in reference to trance, and focuses on the role of the body in performance but not on the role of poetry.

Expanding on earlier writings on the shikhat, and informed by contemporary debates on the intertwinement between the sacred and the secular, as well as sexuality and/in Islam, this article explores the porous boundaries between sakan and nashat by focusing on the articulation of ghram or mshka in the performance of the text of 'L-'alwa'. The 
problematic status of the shikhat in Morocco, coupled with an understanding of the category of sexuality as universal (see Massad 2015: 219), have influenced the scholarly treatment of the poems the shikhat sing and, more particularly, how they engage with passion, desire and eroticism in performance. If on the one hand the poetic ability of the shikhat has been analysed in reference to a universalised understanding of sexuality and, in turn, interpreted as 'subversive' or as 'expressing resistance' (Abdeljamil 1993; Kapchan 1996; Soum-Pouyalet 2007), on the other ghram or mshka have been muted in the works of researchers who have chosen to analyse other themes central to 'aita (Ciucci 2012a; Najmi 2007; Raggoug 2000). Thus, the erotic element of the poetry sung by the shikhat has yet to receive adequate attention.

I ask: what is the role of 'L-'alwa' at a specific wedding celebration? How do passion, desire and eroticism emerge in the performance of this oral text and what do they do? What can an analysis focused on female performers and their poetic utterances-no longer grounded in the agonistic framework of propriety and impropriety-bring to such a debate? Also, in this context, what can this analysis bring to the ongoing debate on the sacred and the secular in the music of Morocco and the region?

These important questions, among others, beg ethnographic investigation and an investigation also framed in reference to sh'abi, a notion of the popular whose aesthetics cannot be disentangled from the 'folk' and that is critical to a sense of Moroccanness which, although changing and adapting in the face of overwhelming changes in the region, is intertwined with an audience constituted by the lower-middle class, rural labourers and the urban working class. To date, the relative absence of a discussion about the porosity between sacred and secular in reference to shabi in Morocco is rather problematic; it limits our understanding to music practices associated with healing rituals (and their staged renditions), with the elites, with a notion of the popular that is intrinsically urban and with an upper and elite class audience engaged with a particular understanding of the West and of its aesthetics. The exclusion of sh ${ }^{\text {a }}$ abi from these conversations inherently undermines the critical role that women performers play in mediating between the sacred and the secular in shi $a b i$, in a genre which is quintessential in Morocco, a genre in which women performers are prominent. Drawing on over a decade of ethnographic research in the Moroccan plains and plateaus, the ethnographic exploration which follows-informed by formal and informal conversations with my Moroccan interlocutors-centres on the analysis of two moments of a performance of 'L-'alwa'.

\section{A sacred sense of place: L-`alwa}

In their introduction to Senses of Place, Steven Feld and Keith Basso (1996: 6) remind us about the importance of ethnographic accounts centred on native constructions of particular localities. To examine the role, but also the significance, of 'L-'alwa' at the wedding celebration in question, it is critical to contextualise it in relation to a shared spiritual heritage associated with a particular saint and with a territory marked by a sacred plot of land which designates the saint's shrine, also known as L-'alwa. The sacredness of ' $\mathrm{L}$-'alwa' is entrenched in local ideas; its effectiveness depends on how well the performers convey the experience of visiting the shrines, and on the intimate relationship between embodiment and emplacement. Drawing from Feld and Basso, I argue that 'L-'alwa', the sakan, should be considered a native construction of place, an account of how 


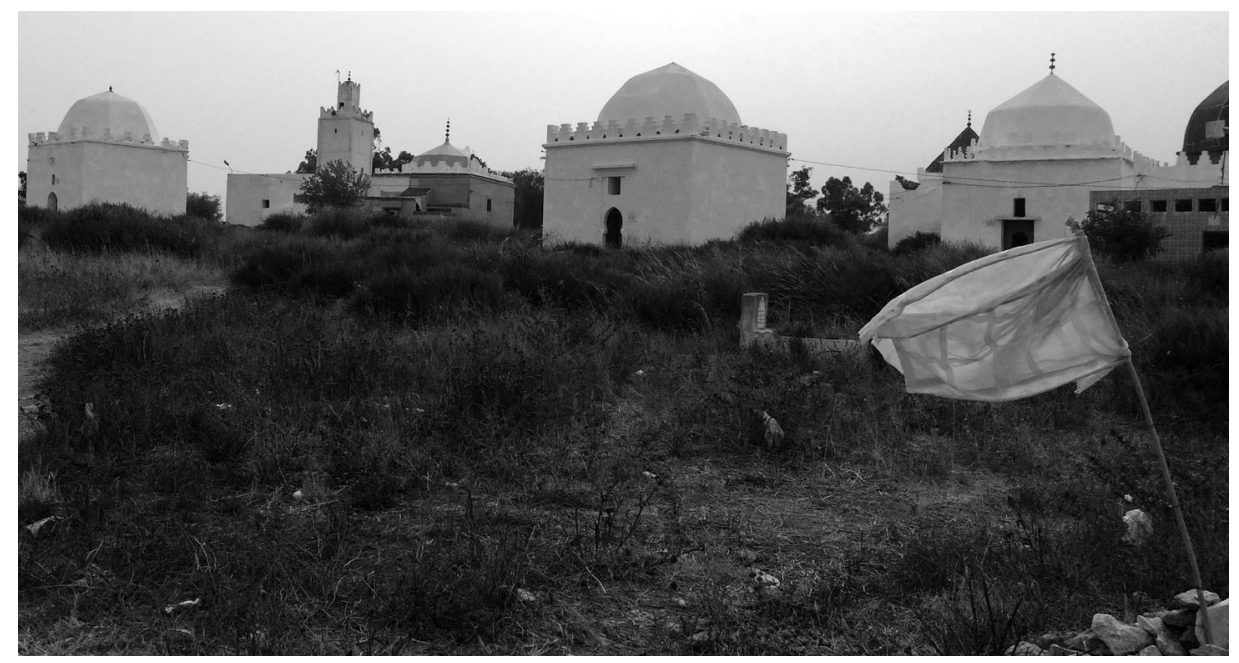

Figure 1. A view of the tomb of Sidi M'hammed Bahloul (next to the minaret) surrounded by some of the other tombs in L-'alwa. Photograph: Alessandra Ciucci.

Moroccans perceive and experience L-'alwa, the place; careful attention, therefore, needs to be placed on the poetic language. To this end, the analysis I propose of this particular sakan explores one way in which L-'alwa is actively sensed (see Feld and Basso 1996: 7), through a localised form of expression.

L-'alwa [lit. the hillock] refers to a small hill between the towns of Ben Ahmed and Sidi Hajjaj in the Casablanca-Settat region in Morocco, where Sidi M'hammed Bahloulknown as the 'boy of L-'alwa' ['azri l-'alwa]_is buried along with some of his descendants and other minor saints as shown in Figure 1. Little is known about this saint, a descendant of the Prophet, who is intrinsically connected with the countryside and the humble. Sidi Bahloul, who was born in Meknes and lived in the seventeenth century, fathered ten sons whose tombs are also located in L-'alwa. His sons, collectively known as l-bhalla [the people of Bahloul], are the ancestors of ten local districts in the region.

As the disciple of Sidi Rahhal al-Boudali (d. 1527), the Sufi path of Sidi Bahloul drew upon the Islamic mystical tradition of the malamatiyya [those who draw blame upon themselves] and shiab al-karamat [people of the miracles]. Sidi Bahloul travelled extensively and lived among a number of tribes in the Casablanca-Settat region; these tribes are collectively known as l-khuddam, the servants of Bahloul (al-Wazzā' 2008: 23-5). Like 'Abderrahman el-Majdoub, the sixteenth-century poet and Sufi figure who is the reputed source of a wealth of Moroccan oral poetry (Boum 2012; De Premare 1985; Rachik 1998; Zouanat 2009), Sidi Bahloul is also the author of many short poems ['arubi] composed in Moroccan colloquial Arabic. ${ }^{5}$

According to the local narrative, these short poems are memorised by a number of older women from the region, collectively known as l-bahlouliyat [the women of Bahloul] (Figure 2), who are considered the guardians of Sidi Bahloul's knowledge and, in turn, of the cultural heritage of the region. The bahlouliyat spend their days in a

${ }^{5}$ For a collection of these poems, see al-Wazzā' (2008). 


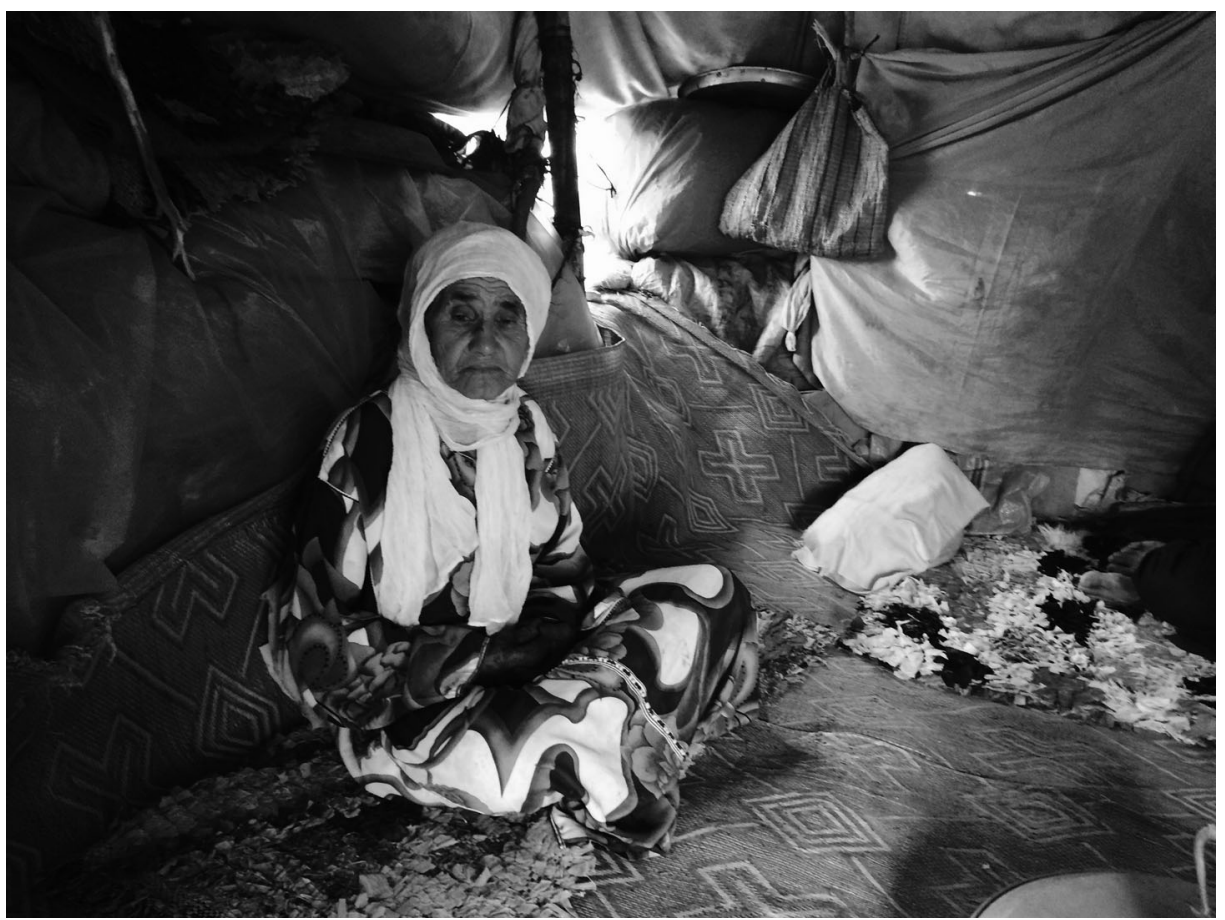

Figure 2. One of the Bahlouliyat in their tent. Photograph: Alessandra Ciucci.

weather-beaten traditional tent near the tombs. After visiting L-'alwa, people visit the bahlouliyat for a glass of tea, to talk about the saint and to listen to them recite the poems of Sidi Bahloul before leaving and making an offering which, in turn, will bring blessing [baraka] to the visitor. ${ }^{6}$ This is how the verses circulate and, at the same time, enter the everyday language in the form of proverbs and sayings. It is through the voice of these women that the oral and aural presence of Sidi Bahloul cohabits with the official visual manifestation of the saint via the shrine. As a sakan, 'L-'alwa' is said to recount the journey of pilgrims travelling from one shrine to the other, and it is thus celebrated for its ability to convey images and emotions stirred by the sacred voyage, and for allowing the audience to have the sense of participating in this experience as if it is occurring.

Saints play a critical role in Morocco, and Moroccans validate these saints by recognising their miracles, visiting them in life and death, and narrating their lives and healing powers. These saints are also recognised as having baraka, which they can communicate to their followers. Baraka - which can only be bestowed by popular attribution-has a great significance in Moroccan culture. Baraka is not lessened but, rather, increased by a saint's death. Thus, by extension, the tombs of the saints-the squat whitewashed buildings with domed roofs [qobbas] which dot the Moroccan territory, marking it, first and

\footnotetext{
${ }^{6}$ Maria Curtis (2015: 329) discusses the role of women ancestors of Moulay 'Abdessalam lbn Mashish in northern Morocco who sing a sung poetry called 'ayoua which they think of as being unique to those villages closest to the shrine.

${ }^{7}$ The people of the region considered the rendition by a male performer of 'aita, Ould Qaddour, as the best. According to my Moroccan interlocutors, Qaddour's knowledge of the geography and of the location of each shrine is what makes the pilgrimage 'correct' and his rendition of this sakən the most successful.
} 


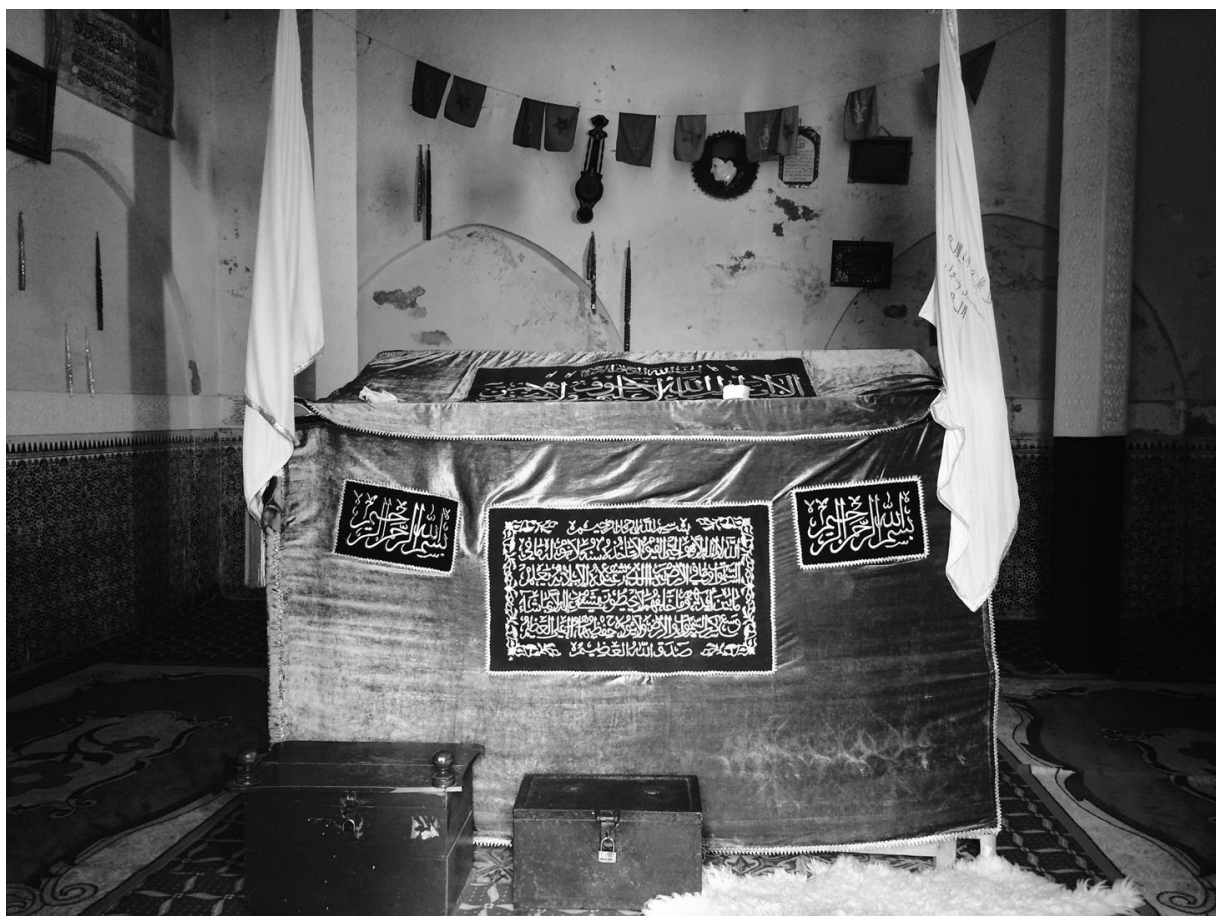

Figure 3. Inside the tomb of Sidi M'hammed Bahloul. Photograph: Alessandra Ciucci.

foremost, as a hagiographic space-are considered to have baraka, and this is why they are visited singly and in groups by pilgrims asking for a cure for any ailment or the fulfilment of individual needs (Figure 3).

A visit [zyara] to these shrines is important, particularly for the less fortunate. This type of pilgrimage, commonly referred to as l-hajj maskin [the pilgrimage of the poor] is regarded, although unofficially, as being equal to the costlier pilgrimage to the shrine in Mecca. ${ }^{8}$ More germane to this discussion, however, is how shrines like that of Sidi Bahloul-more commonly visited by the humble-are generally more frequented by women. Shrines offer women an intimate space where they can express their worries, anxieties or discontents and, at the same time, articulate their desires in accordance with pious practices, seeking through the help of a saint to mediate their place in the external world (el-Ayadi, Rachik and Tozy 2007; el-Haitami 2014; Laghzaoui 1992; Mernissi 1977; Reysoo 1991).

Another important function of shrines is connected to women's sexuality. Women who are eager to find husbands, women whose husbands no longer desire them or women who are concerned about their own sexuality, and who no longer desire their own husbands for example, go to saints to get help and find solutions (Crapanzano 1973; Mernissi 1977; Rhani 2013). Women's concerns are voiced inside these shrines, and they can be

\footnotetext{
${ }^{8} \mathrm{Al}$-Jazouli (d. 1465), a seminal Moroccan Sufi saint, encouraged his followers to visit Moroccan saints when the pilgrimage to Mecca was impossible. It is argued that such a notion helped to establish a local Moroccan spiritual authority generated by the baraka of local saints (Amster 2013: 21-2; Cornell 1998: 180; Nabti 2010: 139). On another 'pilgrimage of the poor' in Morocco, see Curtis (2015: 331).
} 
intimately connected to their visit to shrines. What L-'alwa, as a sacred site, means to Moroccans of the region, to Moroccans who listen to 'L-'alwa' through live and mediated performances, and in particular to women who visit this or other shrines, is intimately intertwined and cannot be overlooked in the analysis of a performance of 'L-'alwa' nor in its role at a wedding celebration. This culminating event, which signals the social and the physical transition of the bride into womanhood, marks her symbolic or actual loss of virginity and her entry into the world of socially sanctioned sexuality. Here, I contextualise a performance of 'L-'alwa' in reference to a celebration, a life-cycle ritual that, implicitly or explicitly, is concerned with women's sexuality. In the analysis that follows, centred on the local notion of ghram or mshka, I draw upon Jeffrey Kripal's definition of eroticism as:

that specifically dialectical manifestation of the mystical and the sexual that appears in any number of traditions through a range of textual and metaphorical strategies which collapse, often together, the supposed separation of the spiritual and the sexual. (2001: 21)

\section{Performing 'L-'alwa'}

It was already dark when we reached the house where the party was to take place. Situated in Oued l-Bacha, a lower-middle class neighbourhood in the city of Safi, the two-story cement house was enclosed by a plot of land that was barely illuminated and crowded with cars. One could immediately sense the festive atmosphere just by looking at the female guests entering the house. Their colourful caftans, stylish hair, make-up, and the amount of gold they wore were in stark contrast to the modest appearances they displayed in their everyday life. Stepping onto the roof felt like stepping into a different world. Covered by a white impermeable tent on the outside, on the inside the roof was clothed by a soft white polyester fabric whose pleats undulated in the gentle summer breeze. Burgundy drapes were arranged around the walls of white cloth, while modern red Rabat-style carpets were spread on the floor. At the end of the roof, directly in front of the entrance, two huge and richly adorned white thrones mounted on a pedestal had been set up for the bride and the groom; they were empty for now. Although large round tables dressed with white tablecloths crowded the space, a corridor had been cleared out that led to the thrones from the entrance. Most of the guests had already sat down but dinner had yet to be served.

When the performers made their entrance, they positioned themselves on the right side of the thrones; the male instrumentalists-Bouch'aib on kamanja [viola], Miloud on the ' $u d$ [Arab lute], Boujm'a on darbuka [large single-skin goblet-shaped drum] and background vocals, and Moustapha and Hassan on bendirs large circular frame drums-sat on the folding chairs with their backs against the cloth wall, while the shikhat stood a few feet away in front of the musicians facing the audience. Hafida and 'Aicha, the lead vocalists, situated themselves in the centre with Khadija and Khoucia, the dancers, by their sides. At about 11:30 p.m., after the bride and the groom sat on the thrones, the celebration finally began. (Fieldnotes, Safi, 11 July 2003)

Musicians commonly prepare a set list which they always adjust in reference to the response of the audience; professionals understand the importance of opening up with a moderate tempo, with a relaxing [markhiya] 'aita to ease the guests into the celebration. Throughout the evening, the performers are careful to shape the right atmosphere. The set list performed that evening is reproduced in Table 1, which helps to contextualise the performance of 'L-'alwa' at this wedding celebration. Together with titles, I have indicated the name of the tetrachords on which the melodies are based, rhythms and their basic subdivisions, tempos and the mood associated with each song. ${ }^{9}$ The prominence of the bayati 
Table 1. Musical plan of the wedding in relation to the tenor of the celebration.

\begin{tabular}{|c|c|c|c|}
\hline Title & $\begin{array}{c}\text { Tetrachords on which } \\
\text { the melodies are } \\
\text { based }\end{array}$ & Rhythms and tempos & Tenor of the celebration \\
\hline ‘Dami' & Bayati on G & $\begin{array}{l}\text { 20-beat slow rhythmic cycle } \\
\text { concluding with a fast compound } \\
\text { duple } \mid=65 \text { beats ca. }\end{array}$ & $\begin{array}{l}\text { Calm, focus on listening } \\
\text { followed by a crescendo } \\
\text { focus on dancing }\end{array}$ \\
\hline $\begin{array}{l}\text { 'T`oriḍa' } \\
\text { (short instrumental } \\
\text { interlude) }\end{array}$ & Bayati on D & $\begin{array}{l}\text { Fast compound duple } \\
\qquad .=70 \text { beats ca. }\end{array}$ & $\begin{array}{l}\text { Crescendo, focus on } \\
\text { dancing }\end{array}$ \\
\hline 'Allah I-ḥbab' & Bayati on D & $\begin{array}{l}\text { Fast compound duple }\rfloor=\text { from } 70 \\
\text { to } 85 \text { beats ca. }\end{array}$ & $\begin{array}{l}\text { Crescendo, focus on } \\
\text { dancing }\end{array}$ \\
\hline 'Dami' reprise & Bayati on G & $\begin{array}{l}\text { Slow compound duple } \\
\qquad .=40 \text { beats ca. }\end{array}$ & Calm, focus on listening \\
\hline 'Lahwawiya' & Bayati on $\mathrm{F}$ & $\begin{array}{l}\text { Fast compound duple } \\
d=74 \text { beats ca. }\end{array}$ & $\begin{array}{l}\text { Crescendo, focus on } \\
\text { dancing }\end{array}$ \\
\hline $\begin{array}{l}\text { Traditional verses sung for } \\
\text { the bride }\end{array}$ & No tetrachord & $\begin{array}{l}\text { Various rhythmic patterns and } \\
\text { tempos accompany the singing }\end{array}$ & Signalling the first break \\
\hline 'Kharja u daira yddia f-iddi' & Bayati on $\mathrm{F}$ & $\begin{array}{l}\text { Fast compound duple } \\
\qquad .=70 \text { beats ca. }\end{array}$ & $\begin{array}{l}\text { Crescendo, focus on } \\
\text { dancing }\end{array}$ \\
\hline 'Nirya' & Ajam on $\mathrm{G}$ & $\begin{array}{l}\text { Fast compound duple } d=\text { from } 70 \\
\text { to } 85 \text { beats ca. }\end{array}$ & $\begin{array}{l}\text { Crescendo, focus on } \\
\text { dancing }\end{array}$ \\
\hline 'Kharbusha' & Bayati on G & $\begin{array}{l}\text { 40-beat, 19-beat, } 10 \text {-beat rhythmic } \\
\text { cycles, concluding with a fast } \\
\text { compound duple } \delta=72 \text { beats } \\
\text { ca. }\end{array}$ & $\begin{array}{l}\text { Calm, focus on listening } \\
\text { followed by a crescendo } \\
\text { focus on dancing }\end{array}$ \\
\hline 'L-'alwa' & Bayati on G & $\begin{array}{l}\text { Slower to faster compound duple } \\
\delta=\text { from } 62 \text { to } 72 \text { beats ca. }\end{array}$ & $\begin{array}{l}\text { Crescendo, focus on } \\
\text { dancing, ecstasy and } \\
\text { trance }\end{array}$ \\
\hline $\begin{array}{l}\text { 'T'ərida' } \\
\text { (short instrumental tune } \\
\text { signalling the end of the } \\
\text { performance) }\end{array}$ & Bayati on D & $\begin{array}{l}\text { Faster compound duple } \\
\qquad .=90 \text { beats cycle }\end{array}$ & $\begin{array}{l}\text { Crescendo, focus on } \\
\text { dancing signalling end of } \\
\text { the performance }\end{array}$ \\
\hline
\end{tabular}

tetrachord reflects its ubiquity in 'aita and, more in particular, in the repertoire of the Ouled Ben Aguida who for decades performed with the lead singer Hafida, and on and off with the co-lead singer 'Aicha. Both shikhat were trained by the late Fatna Bent 1Houcine, one of the most important shikhat in Morocco and the former leader of the group. The predominance of bayati, therefore, is also closely connected to the voice of Fatna Bent l-Houcine who led the group and trained the shikhat who performed at the wedding in question. Further, the difference between long and slower rhythmic cycles with faster compound duple metres signals a shift from listening to dancing, and from performing long poems [qașidas] to performing short poems [barwals].

As the kamanja played the first notes of the melody, soon followed by the other instruments, the sound of 'L-'alwa' began to fill the roof and to catch the attention of the guests who had been cooling off. The Ouled Ben Aguida had resumed playing with the intention of finishing what they had been prevented from achieving when the hostess had brusquely halted the previous song. The musicians knew that this final tune had to produce a last and memorable climactic moment: a sakan was the right medium and its choice was not coincidental.

'L-'alwa' was indeed working; it did not take long for the atmosphere to feel charged: ${ }^{10}$

\footnotetext{
${ }^{9}$ Although the musicians use the term maqam [mode], in reality what they describe is a tetrachord because the range of the melody does not surpass a fourth. For more on the use of the term in reference to 'aita, see Ciucci (2012a).
} 
1. a bismillah bismillah 'la 'ate subhanah wa mula natrajjah a baba mula sidi bu In the name of God, the supreme provider, the divine, Mulay, ${ }^{11}$ we put our hope in him, father, Mulay Sidi Bu. ${ }^{12}$

2. a ya ya l-'alwa fin malik ya bti ra shkun li hadik

l-'ozri 'ainu 'lik tji l-khayl u jibek

L-'alwa where are your people? My daughter! Who takes care of you?

The boy's eyes ${ }^{13}$ are on you. The horses will bring you.

3. wallah ma ngul l-'aib wa la ngulu (a mula!)

fikum li tṣab iṣir l-kafor bin idikum

By God, I'll never say something bad or say it against you, no matter what happens, the ingrate is amongst you.

4. a ya ya ntuma ouled haddou thbosu 'lina l-'du u nshufkum tshahadu u l-khayl jibek

You, Ouled Haddou, ${ }^{14}$ you keep the enemy away from us, we see you testify, and the horses will bring you.

5. a ya ya ntuma ouled hariz a jedkum sharif wa' aziz sal dheb u lwiz lqait khbaru fi bariz You, Ouled Hariz, ${ }^{15}$ your ancestor the noble and the dear one, asks gold and gems, I heard his news in Paris. ${ }^{16}$

6. a ya ya nudi ya l-harizia ya ya bti ra fin mwaddar a jibi l-mkhantar ra sidi 'omar ben lahsen

Get up woman from the Hariz! My daughter! Where have you been?

Bring the one who is well-groomed, Sidi 'Omar Ben Lahsen. ${ }^{17}$

7. a khalluni nabki ya ba khalluni nashki

'la zyara jeddi ya ba ra zaru ma 'muni

Let me cry, father, let me complain,

about the visit to my grandfather, father, they visited him without telling me.

The opening couplets immediately bring forth the sacred quality of 'L-'alwa'-bismillah [in the name of God] is the everyday shorter version of bismillahi ar-rahmani arrahim, a formula used at the beginning of every chapter of the Quran (except for Surah at-Tawbah) and pronounced at the beginning of any public discourse-and are followed by couplets that identify the sacred plot of land and the saint in question so as to

\footnotetext{
${ }^{10}$ recorded this text of 'L-'alwa' at the wedding in question. The verses were transcribed, transliterated and translated together with Abdessadek Boumahchad, and discussed with the Ouled Ben Aguida and a number of Moroccan interlocutors.

${ }^{11}$ Honorific title prefixing the name of a patrilineal descendant of the Prophet.

${ }^{12}$ Mulay Sidi Bu refers to M'hammed I-Bahloul.

${ }^{13}$ The verse refers to the 'boy of L-'alwa', the epithet for M'hammed I-Bahloul.

${ }^{14}$ The name of a tribe and its annexed territory in the Casablanca-Settat region.

${ }^{15}$ The name of a tribe and its annexed territory in the Casablanca-Settat region.

${ }^{16}$ Audiences and musicians explained to me that this verse is as an example of a what happens when a singer forgets something and quickly substitutes it with something else which has a similar rhyme. However, because the verse continues to be sung by these and other performers, it is possible to infer that, although it is not considered authentic to the song, it is now part of contemporary performances of 'L-'alwa', particularly because nobody seems to remember the 'original' verse.

${ }^{17} \mathrm{~A}$ saint whose shrine is located in the Casablanca-Settat region.
} 
unequivocally mark the pilgrimage and its spiritual experience. Thus, if travelling and performing the pilgrimage to shrines is one of the main themes in Arabic poetry, the specificity of this pilgrimage is rendered by local images existing within a tradition from which they cannot be dissociated. The verses, however, also present a locality that goes beyond the actual territory of L-'alwa. Lines four, five and six, in fact, describe shrines closer to Casablanca and, as such, they insert an alternative route to that of the actual pilgrimage.

Another critical element of this text is that it consists of lines comprising semantic or meaning-bearing material, stock phrases (l-khayl u jibek ['the horses will bring you'] at the end of lines two and four), linguistic nuances and purely expressive interjections which can be replaced without affecting the overall meaning and that are referred to as extensions [l-madd]. Furthermore, direct address (nudi ya l-harizia ['get up woman from the Hariz'] in line six), first person (khalluni nabki ya ba khalluni nashki ['let me cry, let me complain'] in line seven), summons (wallah ['by God!'] in line three), proper names (sidi 'omar ben lahsen in line six), kinship terms (baba ['father'] in line one), presentational particles used to demand or to focus the listeners' attention such as $r a$ and $h a$ ['here'], vocative particles such as $a$ and $y a$ to indicate that a person is being spoken to and diminutive forms expressing endearment ( $b t i$ ['my daughter'] in line six) all dramatise the poetic discourse, switching from a shared communal experience to an individual and more intimate experience.

Khoucia and Khadija had now loosened their hair and had begun to rotate their heads side to side to the rhythm of 'L-'alwa.' As their mid-length hair flew in the air, the two shikhat shifted their torsos from one side to the other while keeping their forearms raised halfway in front of them. Their firmly planted feet and slightly bent knees, which supported the shifting of the weight incorporated into these rather demanding movements, supported a stance centred in the lower body. As they turned to face one another, the two shikhat held hands to support each other. The intensity of the performance and of the celebration continued to rise as more and more guests crowded the floor, sang verses of 'L-'alwa,' or rocked their heads to and fro while seated.

The sacred dimension of the voyage was now accompanied by an erotic connection between an internalised and an externalised response and, more in particular, by the 'hair dances' the shikhat performed. Hair dances mark key moments because they symbolise an ecstatic peak for women. Associated with Sufism, ecstasy and trance, hair dances also have a highly erotic connotation, being that women's hair is an attribute of female beauty and appeal that is highly valued although curtailed because of the modest appearances that women need to display in their everyday life. Together with spiritual ecstasy, hair dances may also symbolise a different type of ecstasy.

The sussi-a compound-duple rhythm displaying the characteristic Moroccan duple and triple subdivision of the beats (emphasising beats 1, 4, 7 and 11) kept the momentum going. The Ouled Ben Aguida said they preferred this light rhythm [mizan khfif] to a heavy rhythm [mizan taqil] such as the haddari; it is a better fit for the short verses and for an atmosphere in which dancing is quintessential, for what they describe as being in tune [kulshi tsawa], for the exchange of feelings [tabadul l-ihsas] with the audience. That kind of participation is paramount to the success of any performance.

The second significant moment of this performance was characterised by a crescendo marked by a series of couplets sung by one of the lead singers. At this moment the audience performed a range of affective responses involving facial, gestural and postural elements. 


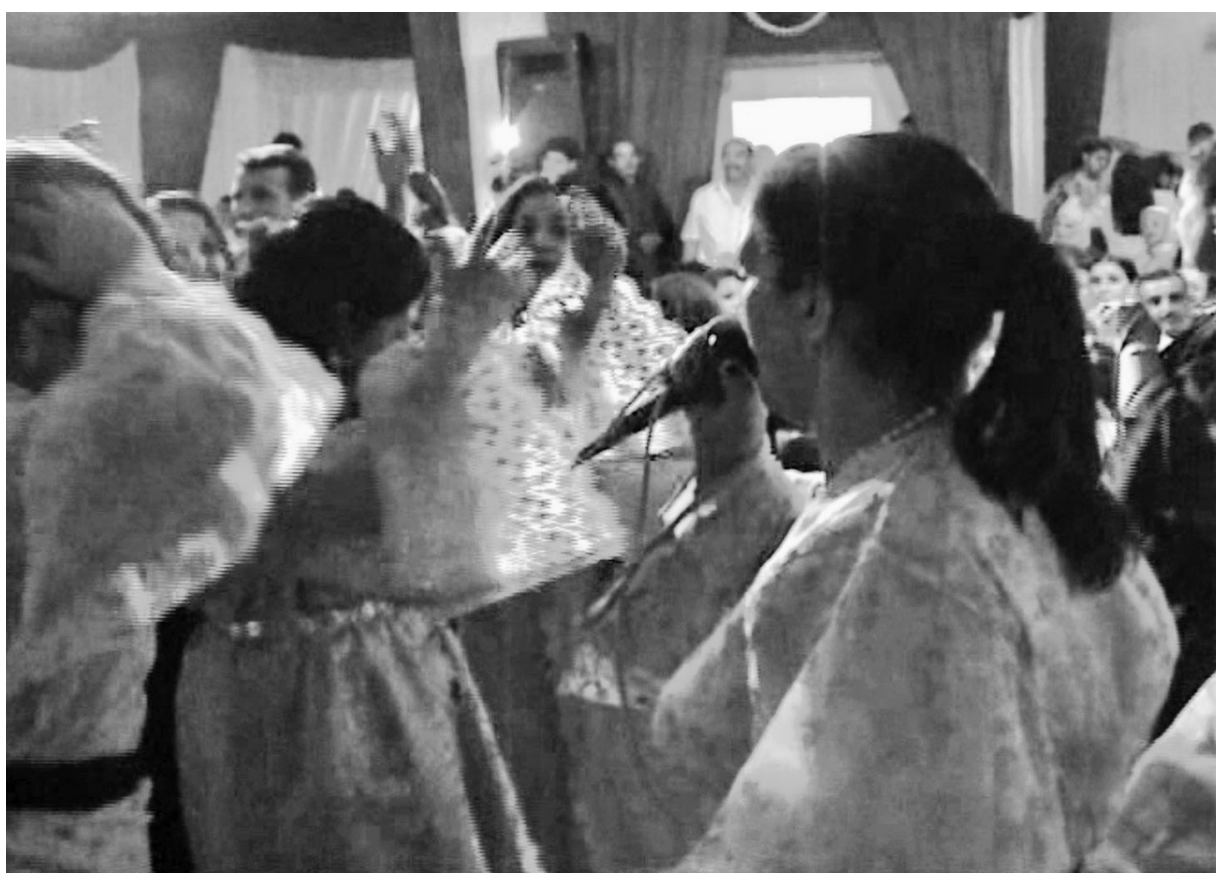

Figure 4. A moment at the wedding celebration. Photograph: Alessandra Ciucci.

As 'Aicha sang, Khoucia held her head between her hands, a movement commonly used to indicate a feeling of intoxication, loss of reason or, a gesture associated with trance (Crapanzano 1973); two female guests opened up their arms lifting them up in the air before swaying their upper bodies back and forth. Khadija moved her head from side to side as older pious women seated away from the performers continued to clap their hands. One of them, however, had got up to dance by herself. At this moment the female guests surrounded 'Aicha and danced in front of her in a sort of frenzy (Figure 4). For these women, 'Aicha seemed to embody, or perhaps replace the absent saint.

Sacredness, as an attribute, is not absolute but it is brought into play by the nature of particular situations (van Gennep [1908] 1960: 12). Meriem el-Haitami (2014: 194) has argued that the realm of spirituality has allowed for the female body to be reinvented and to become 'empty' so as to stand as a symbol of something greater. In the following lines I have indicated with bold font it is possible to see how passion, desire, eroticism and ghram or mshka circulate between female voices and female bodies. More importantly, lines eight, nine, eleven, twelve, fourteen, and fifteen (to my knowledge and to that of a number of Moroccans familiar with this sakən) are not part of 'L-'alwa' sung by Ould Qaddour and by other male interpreters:

8. a bghit shrif l-mken a nshufu b-gac ness torma fi babu u rwaihu maskiya

I want the noble of the region to be seen by everyone, to throw myself at his door, his odours are musk.

9. wa l-khadem ya bti 'agbi la tbki yallah nzuru jeddi wa bu'zbid sherqi 
The servant, my daughter, come back don't cry,

Let's go visit my grandfather, Bou'abid Sherqi ${ }^{18}$

10. ya ra l-bahlouliya ya ya l-kbida nur sadat

l-hay u li mat u l-baqi f-l-hayat

Woman from Bahloul, my love, ${ }^{19}$ the saints' light,

the living, the dead and those who are still alive.

11. u kif l-hajj ihallal ya ya nudu tṣallu l-fjar

u zyara l mulay 'omar ma qadortshi hətta nșbar

When the Hajj prays before dawn, get up to pray the Fajr, ${ }^{20}$

I couldn't wait to visit Mulay 'Omar.

12. wa mezian ma darti ya baba ra shi ma dartu wa haq rabbi l-ma'bud wa shrifi la fallatu

It's good what you have done, father, oh I haven't done anything,

I swear by God that I wouldn't let him go.

13. wa ila bghiti tbki a ya ya tbot'qlak u shki

wa sidi hajj l-makki ya huwa 'la man mtaki

If you wanted to cry, father, hold on to yourself and then complain,

Sir Hajj l-Mekki, ${ }^{21}$ he depends on him.

14. wa l-'ar a sidi bennour a wulidi wa nta ra mashhur wa l-ar a sidi hmed l-ftila la tahmed

I implore Sidi Bennour, ${ }^{22}$ my son, you, the famous one,

I implore Sidi Ahmed not to let the flame die out.

15. wa l-mmwima zini l-hal wa ra ouladi mazal sghar

mmwimti $u$ ana nbki wa samhi ila 'adbtək

My dear mother, my state is beautiful, my children are still young,

my dear mother, I'm crying forgive me, if I made you suffer.

The second half of line eight refers to musk: smell is an important sense in the erotic. On one hand, musk is used to evoke the absent saint; on the other, musk is a fragrance that is enticing. Aside from being one of the preeminent aromatics in Arabic poetry, musk was used in the time of the Prophet: Surah 83, Verse 26 of the Quran tells us: 'The seal thereof [of the pure drinks of Paradise] will be musk: and for this let those aspire, who have aspirations.' That the perfumed drinks of the hereafter are sealed with musk indicates it to be the king of all the scents and, because God printed his name on the seal, musk is the one of the purest and noblest of all earthly matters. In this sense, musk may be also thought as being the aroma of sanctity. Musk, furthermore, is an incense which is burned and used in trance ceremonies in Morocco and beyond (Rouget 1985).

\footnotetext{
${ }^{18}$ This refers to Sidi Mohammed Sherqi, a saint and one of the great Moroccan Sufis. His shrine and zawiya [lodge] are situated in the town of Boujad, located in the Beni Mellal-Khenifra region (see Eickelman 1976).

${ }^{19}$ Literally kbida is the liver, because in popular parlance and poetry it is in this organ, rather than in the heart, that sentiments reside.

${ }^{20}$ The first prayer of the day.

${ }^{21} \mathrm{~A}$ saint whose shrine is situated in the Berrechid region.

${ }^{22} \mathrm{~A}$ saint whose shrine is situated in a town with the same name in the province of el-Jadida. Sidi Bennour is the birth place of the late lead shikha of the Ouled Ben Aguida, Fatna Bent I-Houcine.
} 
In line nine, the 'servant' refers to a woman who attends to Sidi Bahloul and his shrine and, in particular, to a woman from the Mazb tribe in the Casablanca region, because this tribe is identified as the servant of the saint and connected to him through baraka and miracles. However, the word servant also refers here to a minor female saint who is buried in the hillock, Lalla Fatima Khayla [Lady Fatima the Black One]. In the verse the female servant/saint - the one who takes care of Sidi Bahloul and who is directly addressed-is said to represent a female lover who has acted inappropriately and is now being comforted.

'My love' is inserted in line ten; the impatience to visit Mulay 'Omar in line eleven; the swearing not to let him go in line twelve; the imploration not to let the flame die out in line fourteen; and there is also the mentioning of how beautiful is the state in line fifteen. $\mathrm{Hal}$ [lit. state, condition] has a specific meaning in Sufism, where it can be translated as a spiritual state and refers to the idea of 'encounter' (Gardet 2012), to nearness to God or divine intimacy; it is a state descended from God or, in this case, from the saint. The reference to the $h a l$, in this poetic tradition, is known to be a metaphor for a different type of climax; ${ }^{23}$ just like the saint, in line fourteen, it is said to represent the beloved.

The performance continued to intensify and to build tension as the pace of the compound duple metre increased. The sussi rhythm the performers had preferred to the heavier haddari rhythm-associated with the hadra [lit. presence] and with ceremonies steeped in Sufism and trance-was working; guests were used to listening to this light rhythm usually performed in the final section of long poems of 'aita devoted to dancing. 'Aicha and Boujm'a were now singing in close call-and-response fashion. As 'Aicha split verses into fragments, between which the percussionist's onomatopoeic riffs were interpolated, 'L-'alwa' took on an almost mesmerising quality. As the instrumentalists added intensifiers, gradually pressing the rhythm, increasing the tempo, hitting the frame drums with more vigour, bowing the kamanja and plucking the strings of the ' $u d$ with a renewed strength, the musical texture grew denser and denser. The soaring fullchest, full-throated voice of 'Aicha-whose rough or coarse [hərsh] timbre signalled an embodied sound with collectively recognised meanings-stimulated emotions, arousal and communion with the other guests and a climactic moment that caused one of the female guests to fall into trance even while seated at one of the tables:

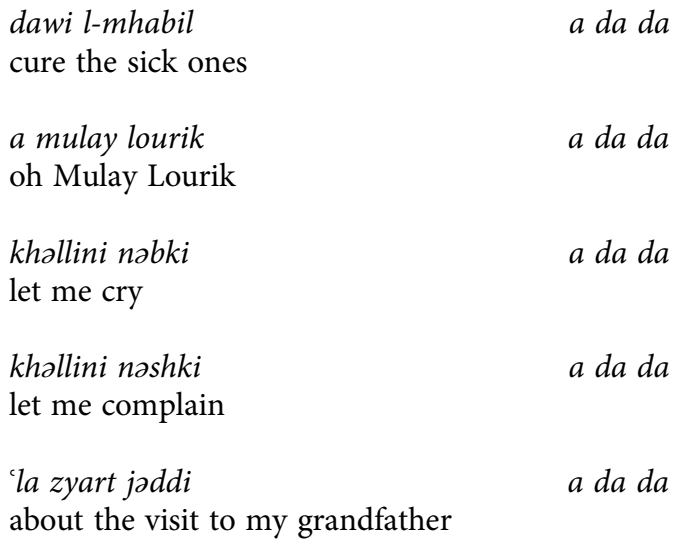

\footnotetext{
${ }^{23}$ In Moroccan Arabic, everyday expressions such as jani I-hal [lit. the ecstasy has come to me] or fih I-hal [lit. the ecstasy is in him] are used as metaphors to describe the need or desire for sexual relations.
} 
zaru ma 'Imuni

they visited him without telling me

ngad nmshi l-bid

I can go as far

hatta ouled said

as Ouled Said

'amri ma nənsak

I will never forget you

wa la nəqta` rjak

nor I will lose hope

'aqli zian miak

my mind is at peace with you a da da

a da da

a da da

a da da

a da da

a da da

\section{Conclusion}

As the last song of the evening, the Ouled Ben Aguida had chosen to perform 'L-'alwa' to mark the final climactic moment of their performance. If on the one hand the popularity of 'L-'alwa' guaranteed the kind of response the musicians sought from the guests, on the other, by performing a sakan, the Ouled Ben Aguida effectively interwove the sacred and the secular in their final performance at this wedding celebration.

The main force of 'L-'alwa' lies in the generation of emotions in the listeners. This affect is grounded at the intersection of sound, gesture and, most importantly, poetics; an affect geared towards the realisation of a connection between inside and outside that is critical to this performance of 'L-'alwa'. Words are necessarily also material, and as such they engage the audience with their sound and feel; the presence of the body, the gestures and the musical elements are complimentary to the text, and help to bring out the poem, to make it tangible rather than overshadowing it. In the tradition of 'aita, the verses are at the centre of the listener's attention. Performers are judged in accordance with their poetic ability and sophistication, their poetic nuances and the ways they choose and use metaphors; shikhat who exaggerate a bodily dimension are scorned because of their lack of expertise (Ciucci 2012a).

Sakans are regarded as vehicles for important texts, which may evoke the same attentive listening as sacred and revered texts do. 'L-'alwa' opened up with 'bismillah', the everyday version of the formula used at the beginning of the chapters of the Quran and before any official or public speech, hence demanding attention to the words which will be uttered as well as giving them power and authority. The eloquence of ' $\mathrm{L}$-'alwa', however, is rather different from that of the Quran or Sufi texts in classical Arabic. Using terse language, a vocabulary anchored in the local and a fragmentary syntax characteristic of the vernacular of the region, 'L-'alwa' inherits but also extends a poetic tradition in which images that draw on local lore are juxtaposed with erotic metaphors characteristic of Sufism. The sacred dimension of 'L-'alwa', however, inherits and extends the poetic tradition of Sidi M'hammed Bahloul, a wali who spoke only through verses while in a constant state of ecstasy, a 'wise fool' who lived among the humble and with whom he shared 
specific cultural practices and aesthetics which do not belong to those with privileges or status. Issues of class cannot be disentangled from the $s^{c} a b$ and the presence of a corporeality that is quite different from the spiritual gatherings of the elites, where the effect of spiritual poems generates inside the subject and independently of the senses (see Asad 2003: 38).

The corporeality of 'L-'alwa' distinguishes its poetic performance from those associated with spiritual traditions practiced by the elites; it may suffice to think of the type of spirituality performed at the annual Sacred Music Festival in Fez (see Kapchan 2008), where eroticism, although uttered, is muted inside the body. The erotic dimension of 'L-'alwa' is embedded in the sh'ab, in a musico-poetic tradition such as 'aita associated, first and foremost, with the shikhat. In this context, the eroticism of 'L-'alwa' works as a thread; it indexes the connection between the sacred and the secular, sakan and nashat; it permeates both categories and allows for their perceived boundary to collapse.

To analyse the poetic expression of the shikhat in reference to a universal understanding of sexuality is problematic; to continue to ground such analysis in an agonistic framework of propriety and impropriety means to repeat tropes associated with women, sexuality in/and Islam uncritically, to perpetuate stereotypes in the literature that need to be revisited (see among others Abu-Lughod 2002; Massad 2015). To silence eroticism, however, is also problematic; it fails to acknowledge the presence of the shikhat in the ongoing debate on the sacred and the secular in the music of Morocco, the critical role that ghram or mshka play in such a debate and the agency of the words of women.

The role of the body in performance, although undeniably critical, should be discussed in relation to the utterances of the shikhat and these, in turn, cannot be analysed as fragments, decontextualised from a poetic tradition embedded in a rich and complex history and tradition. The meaning and function of ' $\mathrm{L}$-'alwa', and more particularly the role of passion, desire and eroticism, must also be examined in the context of performance. As a stage of reflection which focuses on the bride and the public reconstruction of her social persona from unmarried to married, from girl to woman, a wedding celebration in Morocco becomes a context in which the erotic, a form of knowledge and instruction, is conveyed to the bride and to the participants.

In this context, the shikhat have a mediatory function. They must understand the message of 'L-'alwa' and become adequate hosts for the presence of divine-like words infused with the erotic. They must be able to transform the text by inserting a different topography of the pilgrimage so as to bring guests closer to their own experience, insert personal narratives that speak to their audience, gender a text allowing the female guests to actively participate and intertwine the erotic into a sacred voyage which is engaged, rather than abstracted from the sensorium. The shikhat make their bodies into instruments capable of resonating the words they sing, and supply a combination of pleasures, passion and desire by means of the senses in their performance in order for the listeners to smell, touch, taste, see and thus listen to their words. Erotic arousal is stimulated by a sensual overload that is meant to draw the audience into a climax, a state of ecstasy that is both sacred and erotic. As the shikhat become the embodiment of passion-what Adriana Cavarero defines as 'donna-passione' (1995: 310), a woman who has abandoned the domestic image of daughter, wife or mother, a woman who speaks, preaches and, more importantly, writes, or in this case interprets and composes oral verses-the 
agency of the shikhat is to engender and penetrate a sacred dimension entrenched in the culture and the aesthetics of the sh' $a b$, a popular which has been relegated to the secular and to entertainment, and that has been absent from discussions about the porosity between the sacred and secular both in the music of Morocco and in the region at large.

\section{Acknowledgements}

I owe a debt of gratitude to the troupe of the Ouled Ben Aguida whose performance and conversations informed this article. Special thanks to Rachid 'Abdellatif, Mohammed al-Sawti al-Bahlouli and Hassan Najmi who kindly accompanied me to visit L-'alwa and who generously shared their time and knowledge about the site and ' $\mathrm{L}$-'alwa'. Thanks are also due to the two anonymous reviewers, whose insightful comments helped my rethinking of this article.

\section{Disclosure statement}

No potential conflict of interest was reported by the author.

\section{Funding}

This work was supported by the J. William Fulbright Foreign Scholarship Grant for Dissertation Research 2001 (Morocco); American Institute for Maghrib Studies Grant; Jewish Foundation for the Education of Women Fellowship.

\section{Note on contributor}

Alessandra Ciucci is Assistant Professor of Music (Ethnomusicology) at Columbia University. She received her $\mathrm{PhD}$ in music (ethnomusicology) from the City University of New York at the Graduate Center. Her research interests include the music of Morocco, North Africa, the Mediterranean, music and migration, music and gender, sung poetry and the popular music of North Africa. Her articles appear in Ethnomusicology, The Yearbook for Traditional Music, The International Journal of Middle East Studies, Mondi Migranti and Cahiers de musiques traditionnelles, and in several edited volumes.

\section{ORCID}

Alessandra Ciucci (i) http://orcid.org/0000-0001-5954-4641

\section{References}

Abdeljamil, Khadija. 1993. 'L'énonciation dans la chanson populaire arabe de femmes au Maroc (chikhat)'. Ph.D. diss., Université Lumière-Lyon II.

Abu-Lughod, Lila. 2002. 'Do Muslim Women Really Need Saving? Anthropological Reflections on Cultural Relativism and Its Others'. American Anthropologist 104(3): 783-90.

Aguila, Jésus, and Mokhtar Zagzoule. 2000. 'Guide pour l'écoute du CD'. Horizons Maghrébines: Rihla/Traversée: Musiques du Maroc 43: 178-9.

Aidi, Hisham. 2014. Rebel Music: Race, Empire, and the New Muslim Youth Culture. New York: Pantheon Books. 
Amster, Ellen. 2013. Medicine and the Saints: Science, Islam, and the Colonial Encounter in Morocco, 1877-1956. Austin: University of Texas Press.

Asad, Talal. 2003. Formations of the Secular: Christianity, Islam, Modernity. Stanford: Stanford University Press.

el-Ayadi, Mohammed, Hassan Rachik, and Mohamed Tozy. 2007. L'Islam au quotidien: enquête sur les valeurs et les pratiques religieuses au Maroc. Casablanca: Editions Prologues.

Baldassarre, Antonio. 1999. 'With the Daughters of the Houara (Morocco): From Fieldwork to World Music.' Music and Anthropology: Journal of Musical Anthropology of the Mediterranean 4. http://umbc.edu/MA/index/number4/baldassarre/baldae0.htm (accessed 7 July 2016).

Bouhmid, Mohammed. 1992. Broadcast interview by Omar Amarir, Knuz, RTM.

- April 15, 1995. 'Innahum yuriduna al-'aita ka dajijin li jam'i al-Hushudi. As-sulta fi almaghribi lam tafham anna ihtirama al-'aita fi-hi janibun min jawanibi al-hitdi 'la shaksiyatina' [They surely want the 'aita to be the noise of the crowd. The Moroccan authority has not understood that respecting the 'aita means preserving our identity]. al-Ittihad al-lshtiraqi, 6.

Boum, Aomar. 2012. 'Abderrahman El Majdoub'. In Dictionary of African Biography. edited by Emmanuel K. Akyeampong and Henry Louis Gates Jr., 35-6, Vol. 1, New York and London: Oxford University Press.

Callen, Jeff. 2006. 'French Fries in the Tagine: Re-imagining Moroccan Popular Music'. Ph.D. diss., University of California, Los Angeles.

Cavarero, Adriana. 1995. 'La Passione Della differenza'. In Storia Delle Passioni, edited by Silvia Vegetti Finzi, 279-313. Roma: Laterza.

Ciucci, Alessandra. 2012a. "The Text Must Remain the Same”: History, Collective Memory and Sung Poetry in Morocco'. Ethnomusicology 56(3): 476-504.

- 2012b. 'The Study of Women and Music in Morocco'. International Journal of Middle East Studies 44(4): 87-89.

Cornell, Vincent J. 1998. Realm of Saint: Power and Authority in Moroccan Sufism. Austin: University of Texas Press.

Crapanzano, Vincent. 1973. The Hamadsha: A Study in Moroccan Ethnopsychiatry. Berkeley: University of California Press.

Curtis, Maria. 2015. “I Have a Voice”: Despatialization, Multiple Alterities and the Digital Performance of Jbala Women of Northern Morocco'. Hawwa: Journal of Women of the Middle East and the Islamic World 13: 323-43.

Davila, Carl. 2013. Al-Āla: History, Society and Text. Wiesbaden: Reichert Verlag.

De Premare, Alfred-Louis. 1985. Sidi 'Abd Er-Rahman El Mejdoub. Mysticisme populaire, sociéte et pouvoir au Maroc aul6é siècle. Paris: Éditions di CNRS.

Eickelman, Dale. 1976. Moroccan Islam. Tradition and Society in a Pilgrimage Center. Austin: University of Texas Press.

Feld, Steven and Keith Basso, eds. 1996. Senses of Place. Santa Fe, NM: School of American Research Press.

Fuson, Timothy. 2009. 'Musicking Moves and Ritual Grooves across the Moroccan Gnawa Night'. Ph.D. diss., University of California, Berkeley.

Gardet, Louis. 2012. 'Ḥāl.' In Encyclopaedia of Islam, edited by P. Bearman, Th. Bianquis, C. E. Bosworth. E. van Donzel, W.P. Heinrichs. Leiden: Brill. http://dx.doi.org/10.1163/1573-3912_ islam_COM_0254 (accessed on 27 October 2016).

Gennep, Arnold van. [1908] 1960. The Rites of Passage. Translated by Monika B. Vizedom and Gabrielle L. Caffee. London: Routledge and Kegan Paul.

el-Haitami, Meriem. 2014. 'Women and Sufism: Religious Expression and the Political Sphere in Contemporary Morocco'. Mediterranean Studies 22(2): 190-212.

al-Jirari, 'Abbas. 1970. al-Zajal fi al-maghrib: Al-Qașida [The Zajal in Morocco: The Qașida]. Rabat, Morocco: Maktaba al-Ṭalib.

Jouad, Hassan. 2002. 'Le Malhûn'. Música oral del Sur 5: 121-36.

Kapchan, Deborah. 1996. Gender on the Market: Moroccan Women and the Revoicing of Tradition. Philadelphia: University of Pennsylvania Press. 
2003. 'Nashat: The Gender of Musical Celebration in Morocco'. In Music and Gender: Perspectives from the Mediterranean, edited by Tullia Magrini, 251-64. Chicago: University of Chicago Press.

- 2007. Traveling Spirit Masters: Moroccan Gnawa Trance and Music in the Global Marketplace. Middletown, CT: Wesleyan University Press.

- 2008. 'Promise of Sonic Translation: Performing the Sacred Festive in Morocco'. American Anthropologist 110: 467-83.

Karl, Brian. 2012. 'Across a Divide: Mediation of Contemporary Popular Music in Morocco and Spain'. Ph.D. dissertation, Columbia University.

Kripal, Jeffrey. 2001. Roads of Excess, Palaces of Wisdom: Eroticism and Reflexivity in the Study of Mysticism. Chicago: University of Chicago Press.

Laan, Nina ter. 2012. 'Performing dhikr above a Nightclub: The Interplay of Commerce and Spirituality at the Fez Festival of Sufi Culture'. Performing Islam 1(1): 161-70.

- 2016. "Islam Is There to Make People Free:" Islamist Musical Narratives of Freedom and Democracy in the Moroccan Spring'. In Islam and Popular Culture, edited by Karin Van Nieuwkerk, Mark Levine, and Martin Stokes, 81-99. Austin: University of Texas Press.

Laghzaoui, Latifa. 1992. 'Women and Shrines in Urban Morocco: The Case of the Patron-Saint of Salé. Ph.D. diss., SOAS, University of London.

Langlois, Tony. 1999. 'Heard but not Seen: Music among the Aissawa Women of Ouida, Morocco'. Music and Anthropology: Journal of Musical Anthropology of the Mediterranean 4. http://www. umbc.edu/MA/index/number4/langlois/lang0.htm (accessed 7 July 2016).

Lortat-Jacob, Bernard. 1980. Musique et fêtes au Haut-Atlas. Paris: Sociéte Française de Musicologie, Editions Musicales Transatlantique.

Maarouf, Mohammed. 2010. 'Saints and Social Justice in Morocco: An Ethnographic Case of the Mythic Court of Sidi Šamharūšs. Arabica 57: 589-670.

Magidow, Melanie. 2016. 'Trending Classic: The Cultural Register of Moroccan Malhun Poetry.' Journal of North African Studies 21(2): 310-34.

Majdouli, Zineb. 2014. Trajectoires des musiciens gnawa: approche ethnographique des cérémonies domestiques et des festivals de musique du monde. Paris: L'Harmattan.

Massad, Joseph. 2015. Islam in Liberalism. Chicago: University of Chicago Press.

Mernissi, Fatima. 1977. 'Women, Saints, and Sanctuaries in Morocco'. Signs 3(1): 101-12.

Nabti, Mehdi. 2010. Le Aïssawa: soufisme, musique et ritual de transe au Maroc. Paris: L'Harmattan. Najmi, Hassan. 2007. Ghina' al-'Aita: al-Sh'ir al-Shafawi wa al-Musiqa al-Taqlidiyya fi al-Maghrib [The 'Aita: Oral Poetry and Traditional Music in Morocco]. Casablanca: Dar Tubqal li-l-Nashar.

Rachik, Hassan. 1998. 'Imitation ou admiration? Essai sur la santeté anti-exemplaire du majdūb'. In L'autorité des saints: perspectives historiques et socio-anthropologiques en Méditerranée occidentale, edited by Mohamed Kerrou, 107-19. Paris: Éditions Recherche sur les Civilisations.

Raggoug, 'Allal. 2000. 'al-'Ayta: chant du Maroc profond entre musique et histoire'. Horizons maghrébins 43: 16-21.

- 2008. La chanson populaire marocaine: une géographie culturelle diversifié. Rabat: Rabat Net Maroc.

Reysoo, Fenneke. 1991. Pèlerinages au Maroc: fête, politique et échange dans l'islam populaire. Paris: Éditions de la Maison de Sciences de l'Homme.

Rhani, Zakaria. 2013. Le pouvoir de guérir: mythe, mystique et politique au Maroc. Leiden: Brill.

Rouget, Gilbert. 1985. Music and Trance: A Theory of the Relations between Music and Possession. Chicago: Chicago University Press.

Rovsing-Olsen, Miriam. 1997. Chants et danses de l'Atlas: Maroc. Paris: Cité de la Musique/Actes Sud.

Sabry, Tarik. 2010. Cultural Encounters in the Arab World: On Media, the Modern and the Everyday. London: I.B. Tauris.

Salois, Kendra. 2014. 'Make Some Noise Drari: Embodied Listening and Counterpublic Formations in Moroccan Hip Hop'. Anthropological Quarterly 87(4): 1017-48.

Schaefer, John. 2015. 'Observations on Gnawa Healing in Morocco: Music, Bodies and the Circuit of Capital'. Performing Islam 4(2): 173-82. 
Schuyler, Philip D. 1974. al-Milhun: The Fusion of Folk and Art Traditions in Moroccan Song Form. MA thesis, University of Washington.

. 1979. 'A Repertory of Ideas: The Music of the Rwais, Berber Professional Musicians from Southwestern Morocco'. Ph.D. diss., University of Washington.

. 1981. 'Music and Meaning among the Gnawa Religious Brotherhood of Morocco'. The World of Music 23(1): 3-13.

Simour, Lhoussain. 2016. Larbi Batma, Nass el-Ghiwan and Postcolonial Music in Morocco. Jefferson, NC: McFarland.

Soum-Pouyalet, Fanny. 2007. Le corps, la voix, le voile: cheikhat marocaines. Paris: CNRS.

Sum, Maisie. 2011. 'Staging the Sacred: Musical Structure and Processes of the Gnawa Lila in Morocco'. Ethnomusicology 55(1): 77-111.

al-Wazzā', Musțafa. 2008. Al-Kalām al-Makmūl li-Sīdì Amhammad al-Bahlūl: Dīwān 'Azrī al'Alwah [The Perfect Word of Sīdī Amḥammad al-Bahlūl: The Divan of 'Azrī al-'Alwah]. Rabat: Manshūrat al-Zaman.

Witulsky, Christopher. 2016. 'Light Rhythms and Heavy Spirits: Entertaining Listeners Through Gnawa Musical and Ritual Adaptations in Morocco'. Ethnomusicology Forum 25(2): 1-19.

Yaktin, Said. 2008. Preface to Al-Kalām al-makmūl li-Sìd̄̄ Amhammad al-Bahlūl: Dìwān 'Azrī al'Alwah by Mustafa al-Wazzā', 5-9. Rabat: Manshūrat al-Zaman.

Zeghal, Malika. 2009. 'On the Politics of Sainthood: Resistance and Mimicry in Postcolonial Morocco.' Critical Inquiry 35: 587-610.

Zouanat, Zakia. 2009. Le royaume des saints. Graz: ADEVA. 